Article

\title{
Buddhist Medical Demonology in The Sütra of the Seven Buddhas
}

\author{
Adam C. Krug
}

Tibet Himalaya Initiative, University of Colorado Boulder, Boulder, CO 80309, USA; adamkrug108@gmail.com

Received: 27 February 2019; Accepted: 31 March 2019; Published: 9 April 2019

\begin{abstract}
This essay begins with a brief discussion of the marginalization of demonology in the study of both Indian Buddhist traditions and Āyurvedic medicine. Unlike the study of Buddhist traditions in other geographic regions, there has been relatively little scholarship on the dialogue between Indian Buddhist communities and the localized spirit deity cults with which they have interacted for more than two millennia. The modern study of Āyurverda, with few exceptions, demonstrates a similar trend in the marginalization of bhütavidy $\bar{a}$, or demonology, which has constituted a legitimate branch of Āyurvedic medicine from at least the time that the earliest Āyurvedic compendium, the Carakasamhitā, was composed. This essay argues that this lack of proper attention to Indian Buddhist and Âyurvedic medical demonology is symptomatic of a broader, persistent bias in the human sciences. The essay then examines a handful of stories from the Karmaśataka, a collection of Buddhist avadānas, to argue that certain Buddhist communities may have held their own biases against systems of medical demonology, albeit for entirely different reasons. The balance of this essay then concludes with an analysis of The Sütra of the Seven Buddhas that presents this work as an example of Buddhist medical demonology.
\end{abstract}

Keywords: Āyurveda; Buddhist medicine; demonology; kriyātantra; disenchantment

\section{Demonology in the Shadows of Buddhist Medicine}

Paul Demiéville's 1937 article on Buddhist medicine "Byō" for the Franco-Japanese encyclopedic dictionary of Buddhism Hōboggirin was by all measures a landmark survey of the relationship between Buddhism and the healing arts. ${ }^{1}$ Demiéville covers a tremendous amount of ground on the topic, surveying works from Indian, Chinese, and Japanese traditions that reflect what has since become canon in the field of Buddhist Studies - that there existed an active dialogue between Buddhists and the medical sciences in nearly all corners of the pre-modern Buddhist world, beginning with some of the earliest phases of these traditions for which we have data. The relationship between Buddhism and medicine has since become so deeply engrained in the field that the popular analogy of the Buddha as a "king of physicians" and his four noble truths ${ }^{2}$ as pathology, diagnosis, and prescription is a common didactic in many introductory courses on Buddhist traditions. ${ }^{3}$ Thus, the relationship between Buddhism and medicine functions, as it has for such a long time throughout the history of Buddhist traditions, as one of the very first interpretive frameworks through which new students begin to make sense of Buddhist doctrine.

Paul Demiéville (1985).

(Demiéville 1985), pp. 9-15.

Here I refer to chapter three of Rupert Gethin's The Foundations of Buddhism titled "Four Truths: The Disease, The Cause, The Cure, The Medicine." Gethin's book both played a part in my own introduction to Buddhism during my undergraduate studies and is a work that I have seen other scholars use and used myself for introductory courses on Buddhist traditions. See (Gethin 1998), pp. 59-84. 
Demiéville's article established a number of paradigms that still govern the way that the topic of Buddhist medicine is conceived, researched, and presented. At the same time, as any reasonable scholar would hope, the nine decades of research that have passed since Demiéville first published this work have revealed certain limitations to his study. One of these limitations is reflected in a broader aversion in the field toward research on the impact of popular religious traditions-those loosely organized local deity cults that primarily concerned themselves with the mitigation and propitiation of both benevolent and potentially harmful spirit beings-on the formulation and spread of Indian Buddhist traditions. This aversion extends into the subfield of the study of Indian Buddhist medicine.

To be fair, Demiéville did actually leave some room for exploring this area of Buddhist medicine in his three-fold rubric for Buddhist healing practices. Here he lists "religious therapeutics (good works, and practices of worship, expiation, meditation, etc.), magical therapeutics (mantras, incantations, esoteric ritual), and medical therapeutics proper (dietetics, pharmacy, surgery, etc.)" ${ }^{4}$ as the three primary categories under which various forms of Buddhist medicine might be categorized. He then immediately disrupts his own rubric, rightfully adding that "[t]he lines demarcating these three fields are not at all distinct" ${ }^{5}$ It should also be noted that, in general, scholars working on Chinese Buddhist traditions, perhaps due to the work of scholars like Demiéville and more recently Michel Strickmann, ${ }^{6}$ exhibit a far greater level of sophistication in their understanding of Buddhism's interaction with local religious traditions than scholars who work on the Indian traditions. The same might also be said for scholars working in other cultural-geographic regions to which Buddhism spread such as Tibet, Japan, and Korea. ${ }^{7}$ It is also the case that some progress has been made in the field toward engaging Buddhist sources that might fit Demiéville's category of "magical therapeutics," as is clearly evident in a recently published anthology of pre-modern sources on Buddhist medicine. ${ }^{8}$ Still, for all of their prescience, Demiéville's words of caution against taking too rigid an approach to his structural division of Buddhist medicine into religious, magical, and medical therapeutics seems to have done little to encourage future generations of scholars to fully acknowledge and integrate Buddhist demonology into the mainstream of the study of Buddhist medicine. Instead Buddhist demonology, which deals with the treatment of illnesses that are brought on by demonic possession, has remained at the fringes of what most scholars of Buddhist studies are comfortable referring to as medicine proper. This is symptomatic of a broader problem, particularly in the study of Indian Buddhist traditions, in which the field continues to ignore or marginalize evidence of Buddhists' ongoing dialogue with, and assimilation of, localized popular spirit religions. $\dot{n}$

Robert Decaroli exposes some of the fallacies and problems inherent to this marginalization in his field upending work Haunting the Buddha: Indian Popular Religions and the Formation of Buddhism. He draws our attention to the fact that, in nearly all cases, the attempt to explain the integration of worldly deities associated with popular spirit religions at many of the earliest Indian Buddhist archeological sites "has been cast in pejorative or judgmental terms".$^{9}$ In response to one such line of reasoning, Decaroli argues that the idea that the educated monastic Buddhist elite did not actually believe that the world was populated by spirit beings establishes a rather untenable position that they

(Demiéville 1985), p. 6.

Ibid, p. 6.

See Michel Strickmann $(1996,2002)$.

Here I would argue that we can see the remnants of the search for a "pure Buddhism" working to the benefit of scholars who study Buddhist traditions outside of India. Free from the specter of a "pure" or "original" Buddhism that continues in many ways to haunt the study of Indian Buddhist traditions, scholars who work in other areas of the Buddhist world such as China, Tibet, Japan, and Korea tend to more readily take up the dialogical process of Buddhist assimilations to local cultures as a positive field of study instead of burying these processes behind an obsession with the origins of tradition.

8 (Salguero 2018). Salguero has done a fantastic job organizing an eclectic range of texts related to the study of Buddhist medicine in this anthology. But while it includes a wealth of sources that fit Demiévile's category of "magical therapeutics", the anthology still falls under the general critique that I voice in this essay that Buddhist demonology continues to be ignored in both Buddhist Studies and the study of Buddhist medicine. The contributions from Michael Slouber brush up against the Indic Buddhist demonological literature but focus largely on treatments for snakebite.

9 (Decaroli 2004), p. 9. The same can be said, I would add, about the integration of these deities into Buddhist literature. 
did not participate in the culture in which they were embedded and instead willfully misrepresented themselves to the public as arbiters of the spirit world simply to open up a viable source of economic support. ${ }^{10}$ Thankfully, the overtly pejorative tone adopted in the early decades of the field concerning the Buddhist monastic sangha's direct participation in an Indian cultural milieu in which popular spirit religions were a strong presence has long been abandoned. The legacy of this early phase of scholarship, however, is still apparent in the enduring lack of research on the interaction of Buddhism and Indian popular religions. The openly negative attitude toward such phenomena in the early decades of the field has given way to a position that is neutral at best. In the absence of strong, affirmative arguments for the important relationship between Buddhism and Indian popular religions, the fruits of this relationship found in the vast amount of Indian Buddhist literature containing the ritual theories and practices for managing a world overrun by demonic beings has remained understudied and underappreciated. One corrective to this problematic methodology, as I have argued elsewhere, can be found in the adoption of a demonological paradigm in the study of South Asian religious traditions. ${ }^{11}$ Until such corrective measures are taken seriously, Buddhist demonology will remain hidden in the shadows of Buddhist Studies.

Decaroli's work stands out as an example of what scholars might gain by taking an affirmative approach to the relationship between popular religion and the formulation of Buddhist traditions in India. ${ }^{12}$ As he notes, Buddhist stories about the conversion of demonic spirit beings provide supporting narratives for the assimilation of independent, localized spirit deity cults, and these narratives are as much about the conversion of a particular group of people as they are about the conversion of a local $n \bar{a} g a$, yakșa, or yaksinī. ${ }^{13}$ In this way, accounts of the spread of Buddhism across India are often found in literary and epigraphic sources that document the tradition's dialogical relationship to Indian popular religion. Decaroli's work provides an explicit and affirmative argument that Buddhists' engagement with Indian popular religion, broadly conceived, as an important historical force in the formation of Indian Buddhist traditions. To push this argument a bit further, this also implies that the study of Buddhist demonology—a subset of Buddhists' engagement with Indian popular religion that contains a range of specifically Buddhist claims to knowledge and power over the world of potentially demonic spirit beings-can provide important data not only for understanding the process of conversion but also for understanding the discursive construction of Indian Buddhist identities more broadly. For such sources often speak of more than just the conversion of a local spirit deity cult and its followers-they speak to the question of how to be a Buddhist in a world that is overrun by potentially demonic spirit beings.

Such is the case in the opening narrative of the Śârdulakarnāvadāna. Here the young outcaste girl Prakrti falls in love with Ānanda after encountering him at a local spring and forces her mother to perform a spell (vidyāmantra) to attract Ānanda to their home make him her husband. An analysis of the spell tells us that the form of magic Prakrti's mother practices involves the propitiation and supplication of a particular class of possessing being (graha) through the performance of a mandala and fire-offering ritual (homa) ${ }^{14}$ Caught in the grasp of the mother's attracting spell, Ānanda appeals to the Buddha for help, prompting the Buddha to recite his own spell to release his attendant. The denouement of

\footnotetext{
(Decaroli 2004), p. 10.

(Krug 2018), pp. 15-95.

12 Richard Scott Cohen's work on the role of the yakṣin̄ī Hārītī at the Ajanta cave complex is also a notable contribution. See (Cohen 1998).

13 (Decaroli 2004), p. 44.

14 (Vaidya 1959), p. 314.Sanskrit:amale vimale kuñkume sumane I yena baddhāsi vidyut I icchayā devo varșati vidyotati garjati I vismayaṃ mahārājasya samabhivardhayituṃ devebhyo manuṣyebho gandharvebhạ śikhigrahā devāं viśikhigrahā devā ānandasya āgamanāya saimgamanāya kramaṇāya grahanāya juhomi svāhā I Translation:Pure, stainless, saffron colored, benevolent one who brandishes the thunderbolt - when you so desire, the deity sends forth rain, lightning, and thunder. From among the gods, human beings, and gandharvas, you sikhagraha deities, you visikhagraha deities pique [even] a great king's wonder. I make this fire offering so that Ānanda may come, so that he may meet with us, so that he may approach, and so that he may be bound.
} 
this opening episode to the Śârdulakarnāvadāna then leads us to an important statement from Prakrti's mother, who explains to her daughter that her own tradition of mantra is no match for the Buddha's mantras. ${ }^{15}$ This sets the stage for Prakrti's eventual conversion and ordination into the Buddhist sangha, and for a broader discussion of the issues surrounding the ordination of low caste members of society. But the opening narrative of the Śârdulakarnāvadāna also has something to tell its audience about the relationship between the Buddhist sangha and popular Indian spirit deity cults. The text engages in a polemic against a popular form of sorcery rites that enlist spirit beings to do one's bidding-a religious formulation that we might refer to as popular demonology. The purpose of this polemic, however, is not to discount the efficacy of such rites, but to argue for the superiority of the Buddhist version of essentially the same ritual techniques.

Even the Buddha's mantras, however, have their limitations in the Śärdulakarnāvadāna. When Ānanda returns to the Buddha's camp, Saakyamuni goes on to teach him a spell that can be used to incant a protection cord, telling him that anyone who wears this cord on their arm will have good luck and be protected, unless their misfortune is due to that individual's karma from a previous life. ${ }^{16}$ Thus the Śărdulakarnāvadāna limits the apotropaic power of the Buddha's spells by refusing to grant them the ability to overcome the effects of karma. The reasons for this tension between karmic and demonic pathology in Buddhist medicine is discussed in greater detail below in the context of another collection of avadānas, the Karmaśataka.

Before continuing, it is worth taking a moment to point out the parallels between this strategy and those missionizing strategies that appeal to the Buddha as a "king of physicians." Just as the argument that the Buddha's mantras are superior to all worldly mantras reveals a tradition in active dialogue with Indian popular religions, so too the characterization of the Buddha as "king of physicians" tells us of a tradition in active dialogue with Indian medical traditions. And just as the Buddha's mantras are said to be superior to all worldly mantras, the trope of the Buddha as a "king of physicians" establishes the Buddhist sangha's authority over all worldly medical sciences. ${ }^{17}$

\section{Demonology in the Shadows of Scholarship on Āyurveda}

Among the medical sciences, and featured in all three of the three of the "great trilogy" (bhrhattray $\bar{\imath})$ of Āyurveda-the Caraka-, Suśruta-, and Aștangahrdayasaṃitās-we find another body of knowledge that is engaged in dialogue with popular demonology and the world of spirit beings. Much like the demonological material in Buddhist literature, this body of knowledge, which the Âyurvedic literature actually classifies as "demonology" or "the science of spirits" (bhütavidy $\bar{a})$, provides an example of the formal and systematic codification of a key aspect of Indian popular religion. And much like demonology in the study of Indian Buddhist traditions, bhütavidya shadow of modern scholarship on Āyurveda and the traditional Indian medical sciences.

The marginalization of demonology in the modern study of Āyurveda is parallel to the marginalization of Buddhist demonology in the field of Buddhist Studies. At the level of contemporary popular consumption, there seems to be little room for preserving Âyurvedic demonology as this traditional medical science is rebranded and promoted as a modern health movement in India and

15 Vaidya 1959, p. 315.Sanskrit:balavattarāh śramaṇasya gautamasya mantrā nāsmākam I ye putri mantratāh sarvalokasya prabhavanti, tān mantrāñ śramaṇo gautama ākāin kṣamāṇạ pratihanti I na punarlokah prabhavati śramaṇasya gautamasya mantrān pratihantum I evam baliavattarāh śramanasya gautamasya mantrāh | I Translation:"The ascetic Gautama's mantras are extremely powerful, ours are not. My child, when he wishes, the ascetic Gautama can counteract all the mantras that have power over the entire world. Moreover, a worldly [mantra] is not able to counteract the ascetic Gautama's mantras. Thus the ascetic Gautama's mantras are the most powerful."

16 Vaidya 1959, p. 316.Sanskrit:rakṣāsūtre bāhau baddhe svastyayane kṛte abhibhavitum śaknoti varjayitvā paurāṇam karmavipākam | | Translation: When one ties the protection cord to one's arm it brings good luck. It is able to overpower [anything] except the ripening of karma from a previous life.

17 This dynamic was noted as far back as Demiéville's early article on Buddhist medicine as well in his treatment of an episode from the Mahāparinirvānasūtra. See Demiéville, Buddhist Medicine, 17. 
abroad. ${ }^{18}$ In his dissertation on "Gāruḍa Medicine: A History of Snakebite and Religious Healing in South Asia", Michael Slouber makes the following cogent observations of this problem in the study of Āyurveda:

Selection of passages also plays an important role in persuasive writing. Few people in modern times are aware that classical Âyurveda counted bhütavidyā and agadatantra as two of its eight fundamental branches... In modern Āyurvedic colleges these topics are barely part of the curriculum to the point that many Âyurvedic doctors are not even aware of them. I will not even speak to the degree to which Āyurveda is "sanitized" for export to an American audience. ${ }^{19}$

This pattern of selective amnesia often finds its counterpart in the exclusion of demonological elements from Buddhist meditation traditions that are mass-marketed for modern practitioners. In both cases a very familiar assumption that modernity necessarily entails a Weberian "disenchantment of the world" has perhaps too hastily been adopted. ${ }^{20}$ Scholarship on the historical dimensions of Āyurvedic traditions does push back against this problem, but just as we can observe in the study of demonology in Buddhist medicine, traces of this same marginalization remain.

Dominik Wujastyk's 1999 article "Miscarriages of Justice: Demonic Vengeance in Classical Indian Medicine" opens with a poignant example of the cultural bias against the logics of demonology that lies at the root of its marginalization within the study of Āyurveda and Buddhist medicine. Wujastyk opens by citing the title of one of Carl Sagan's last works, The Demon-Haunted World: Science as a Candle in the Dark. The initial title of the book, drawn from the İśa Upanișad, acts as the foil against which the central concerns of Sagan's own work are brought into relief-to promote science (and no-doubt a form of popular Scientism) as the necessary means for eradicating all "pseudo-science, unreason, and 'demonólatry'". ${ }^{21}$ Wujastyk responds to the alarmist Scientism in Sagan's book by noting that "[t]he rise of unreason in its various guises is not to be taken lightly, and whatever our view of the details of Sagan's arguments, we do well to think seriously of some of the darker consequences of dogmatism and superstition, from which science is not immune either, of course" ${ }^{22}$

I would like to take Wujastyk's observation a step further. Given the fact that some form of belief in supernatural beings can be found in nearly all corners of the contemporary world, I suggest that it is time that we count the historical misrepresentation and habitual marginalization of those

18 The great oversight in this rebranding is that the basic belief in the presence and demonic influence of spirit beings and both the popular and more institutional demonologies that protect people from their harmful effects are both still alive and well across South Asia. In addition, some form of this phenomenon is arguably thriving in nearly all of the world's cultures, even among those living in the allegedly "demystified" modernity of Europe and the Americas. See the note on The Myth of Disenchantment below.

19 (Slouber 2012), p. 15.

20 While the phrase is most readily attributed to the German Sociologist Max Weber, the interpretation of Weber's statements on the disappearance of religious belief, particularly belief in magic, as a characteristic of modern rational scientific thought has a deep history of its own. On a thorough treatment of this issue see Josephson-Storm 2017. In the opening chapters of his survey of the authors responsible for establishing the core canon of the Human Sciences, and Religious Studies in particular, Josephson-Storm provides quantitative data to demonstrate for the reader that the majority of people living in a so-called "disenchanted" modernity in the United States and Europe continue to believe in some form of supernatural power. This effectively allows Josephson-Storm to expose the humanistic impulse toward positing a disenchanted modernity as, ironically, simply another form of mythmaking. After providing evidence that the disenchantment thesis itself is a myth, Josephson-Storm spends the balance of this work discussing the close affinity between many of the most important humanistic thinkers of the twentieth century and the occult. Through his analysis, he effectively exposes the Human Sciences' own selective amnesia in the preservation and transmission of these thinkers' work as evidence of an almost cultic commitment to perpetuating the myth of a disenchanted modernity.

21 (Wujastyk 1999), pp. 256-75.

22 (Wujastyk 1999), p. 257. As Wujastyk points out, Sagan, via Tolstoy, evokes a correlation between the rise of "unreason" and the rise of fascist totalitarianism in twentieth century Europe. But any such argument for the centrality of reason would have to ignore the pivotal role that scientific and technological advances of the nineteenth and early twentieth century such as mechanized warfare, the "science" of eugenics, and the pervasive influence of the epoch-defining scientific theory of Darwinian natural selection along with its racist misrepresentation in the "science" of social Darwinism played in the rise of European fascism. To ignore such data seems, to me at least, to be a violation of the scientific method and thus quite un-scientific. 
peoples for whom modernity and the belief in spirit beings posits no contradiction as one of the darker, more violent consequences of a humanistic science that, adopting an ethos suited to its own central mythology, seeks to eliminate all traces of demonology from the human sciences. This ethos is so pervasive that it has a tendency to crop up even in the work of scholars who do not readily affirm the mythology of a "disenchanted" modernity.

Wujastyk's presentation of bhütavidyā in his most widely accessible work, The Roots of Ayurveda, is a good example of this problem. This work, which was edited and published for a broad, non-specialist audience, arguably gives the impression that demonology was somehow located on the fringes of Âyurveda. Nothing could be further from the truth in a literary tradition whose core three compendia all count demonology as an important division of the medical sciences. Wujastyk is of course aware of this fact, and in all fairness his decision to largely avoid the material on demonology from the Caraka, Suśruta, and Aștāngahridaya-samhitās could simply be a function of the vast scope of the literature. What's more, his decision to draw upon the Kāsyapasamhitā for the section of The Roots of Ayurveda that does discuss bhītavidya certainly affords him the opportunity to expose his reader to the broader Âyurvedic textual traditions beyond these core three compendia. But it also seems to suggest that the core compendia of the Āyurvedic corpus are concerned largely with what contemporary readers would consider more "rational" approaches to pre-modern medicine, while the classical medical science of demonology is something associated with a relatively rarified text, the Käsyapasaṃitā, which, in Wujastyk's own words, has "barely reached the twentieth century". ${ }^{23}$ Here, Wujastyk refers to the fragmentary state in which the manuscripts of the Káśyapasamhitā were found, the first of which was rediscovered by Haraprasād Śāstrī near the turn of the twentieth century and the second by Hemarāja Śarman prior to $1938 .{ }^{24} \mathrm{He}$ also describes the language of the Kāśyapasaṃitā as preserving "certain archaic features" such as the varanabandha, a relatively rare term for a group of rites for protecting pregnant women from demonic attack. ${ }^{25}$ All of this has the unfortunate and perhaps unintended consequence of presenting demonology as an outdated medical science from the fringes of the Âyurvedic textual tradition that just happens to have barely reached the "modern" world in the form of the fragmented manuscripts of the Kāśyapasam hitā. The fact that traces of the marginalization of Âyurvedic demonology appear even in the work of a scholar who is so clearly aware of its importance to Indian medical traditions is perhaps testament to the centripetal effect that the charter myth ${ }^{26}$ of a disenchanted modernity still exerts on research in the Human Sciences.

Perhaps no other work has been more successful at pushing back against this problem and advocating for the central importance of bhütavidy $\bar{a}$ and the broader phenomenon of demonic possession in South Asian literature than Frederick Smith's work in The Self Possessed: Deity and Spirit Possession in South Asian Literature and Civilization. Much as Decaroli has done in the context of Buddhist demonology, Smith takes an affirmative approach to the centrality of spirit possession throughout South Asian literature, crafting a genealogy of the language and mechanics of possession from the Vedas to the emergence of the devotional and tantric religious movements that have dominated South Asian religion from the mid-first millennium CE to the current day. Smith also notes a pattern in the expansion of Āyurvedic demonology from the Suśrutasaṃitā to the Aștāingahrdayasaimhit $\bar{a}^{27}$ that locates the period of increased Āyurvedic development of its demonology in the first half of the first

23 (Wujastyk 2003), p. 163.

24 (Wujastyk 1999), p. 266.

25 (Wujastyk 2003), p. 167; (Wujastyk 1999), p. 266. While the term itself might rightfully be considered "archaic", the practice and the central problem with which it is concerned (i.e., protecting pregnant women from demonic attack) are extremely common from the classical and medieval literature to the current day.

26 Here I borrow a term from Tibetan Studies that is attributed to the work of Samten Karmay, who uses the phrase to describe the function that myth holds for justifying the performance of ritual in Tibetan culture. This is noted in (Cantwell and Mayer 2010), p. 76. Cantwell and Mayer cite (Karmay 1998), pp. 288-89, and elsewhere.

27 (Smith 2006), p. 482. 
millennium CE-during precisely the same period that the codification of an even more expansive Buddhist demonology was taking shape in the dhāraṇ̄ and kriyātantra literature.

\section{Emic Resistance to Buddhist Demonology in The Karmaśataka}

The argument that engagement with local spirit deity cults played a significant role in the development of Indian Buddhism does not entail that all Indian Buddhist textual traditions supported the development of a Buddhist medical demonology. In fact, there appears to have been some resistance to this development. In some circumstances, this resistance may have been a function of the broader ambivalence toward practicing medicine observed in the various Buddhist monastic codes (vinaya), for instance, which supported the study and practice of medicine by and for one's fellow monastics while discouraging members of the monastic sangha from acting as physicians to the lay community. The potential reasons for such prohibitions range from the belief that engaging in medical practice is a distraction from pursuing religious goals to the need to establish a clear niche for which the Buddhist community could claim expertise over and against other contemporary ascetic groups. ${ }^{28}$ But there is another reason that some Buddhists may have been wary of developing their own medical demonology: the logic of demonic possession complicates and even potentially contradicts the Buddhist understanding of karma, one of the most important early doctrinal features that allowed early Buddhists to distinguish themselves from other ascetic movements. ${ }^{29}$

Not only was the popular body of knowledge from which a Buddhist medical demonology drew not exactly Buddhist in origin, integrating the logic on which it operated into the Buddhist system of karma was potentially problematic. As Smith has shown, the South Asian literature on demonic possession consistently explains spirit possession in moral terms. ${ }^{30}$ This seemingly pan-South Asian ${ }^{31}$ correlation between morality, demonic possession, and mental illness (or simply illness) operates within the same conceptual domain as the Buddhist doctrine of karma. This overlap is clear in the Âyurvedic understanding of therapies that rely on spiritual means (daivyapāśraya) outlined as early as the Carakasam $h_{i t} \bar{a}^{32}$ This category encompasses some of the most intractable illnesses, which are understood as either the result of the ripening of karma (karmavipāka) and/or interference from some demonic being. ${ }^{33}$ But there is evidence that medical thought within certain Indian Buddhist textual traditions may have resisted grouping karma and demonic possession together as pathologies requiring therapeutic treatments that rely upon spiritual practices. The reason for this reluctance may very well have been the fact that demonic possession has the potential to disrupt the important role that the doctrine of karma played in Buddhist systems of ethics, particularly before the Mahāyāna schools' rise to dominance. The idea that the negative effects of an individual's actions might be visited upon them through an intermediary spirit being creates a potential fracture in the Buddhist system of karmic

28 (Fiordalis 2018), pp. 105-12.

29 For a thorough presentation of the Buddhist doctrine of karma as a uniquely psychologized adaptation of the broader understanding of karma among the ascetic (śramana) movements that preceded and were contemporary to the formulation of the early Buddhist sangha, see Johannes 2016.

30 As Smith notes the same can be said of mental illness in a more general sense. (Smith 2006), p. 473.

31 It is even relatively conservative to call this a pan-South Asian phenomenon. The correlation between morality, demonic possession, and mental illness (or just illness) is by no means an exclusive to South Asia. Remnants of this correlation, particularly between mental illness and morality, persist among certain "Western" cultural discourses to this day.

32 As Smith notes, the verse that is most often quoted by contemporary Āyurvedic physicians at the beginning of any discussion of the treatment of mental illness is as follows: When it takes the form of disease, a moral transgression effected in another birth may be overcome through rituals of pacification [śānta], medicines [aușadha], gift giving [dāna], repetition of the name of god [japa], fire offerings [homa], temple offerings [arcana], etc. ${ }^{32}$ Sanskrit: janmāntarakrtam pāpam vyādhirūpeṇa jāyate I tacchāntair aușadhaih danaih japahomārcanādibhih I I (Smith 2006), p. 471. Smith notes here that none of his informants could tell him the source for this verse, and he could not locate it himself.

33 The overlap in both pathologies is evident in Carakasamhitā 6.9.16, which introduces the topic of demonology or bhütavidyā: "Externally induced [āgantu] [madness, unmāda] has as its [direct] cause attacks [abhidharṣanāni] by gods [deva], seers [rși], celestial musicians [gandharva], flesh-eating demons [piśāca], semidivine protector demons [yaksa], dangerous demons [raksas], and deceased ancestors [pitr]; [indirectly] it is the result of incorrectly performed internal and external vows, etc., and actions from a previous existence." Translation from (Smith 2006), p. 488. 
retribution. This fracture opens the door to developments such as rituals for apotropaic intervention that could undermine the psychological and ritual mechanics of intention and confession that govern the relative weight of karmic retribution in Buddhist systems of ethics. ${ }^{34}$

This is just one potential reason that certain Buddhist sources preserve a tension around the relationship between karmic retribution and the pathology of demonic possession. The Sütra of the Seven Buddhas, discussed in the next section, is a good example of a text that attempts to navigate this tension in a relatively inclusive way. But before moving on to this work, it will be helpful first to look at a text that takes a more exclusive approach to the problem and adheres more closely to the argument that karma is the sole cause of illness and physical maladies as well as the sole means of attaining some measure of freedom from them. This approach is showcased in a handful of stories from the Karmaśataka (Las brgya tham pa), a compilation of Buddhist avadānas that each contain one or more lessons on the workings of karma. ${ }^{35}$

The Karmaśataka has been traced to the Sarvāstivāda School and is thought to date to the early centuries $\mathrm{CE}$, though it is entirely possible that the works it contains preserve older material. ${ }^{36}$ Originally composed in Sanskrit (or perhaps a Sanskritic vernacular dialect), the text survives only in its Tibetan translation. ${ }^{37}$ While the Tibetan translation does not contain a colophon, the title of the work does appear among the "Basket of Lesser Vehicle Sūtras" (theg pa chung ngu'i mdo sde) in the Dénkarma (ldan dkar ma) royal Tibetan catalogue of translated works, which indicates that it was translated into Tibetan by at least the early ninth century. ${ }^{38}$ The basic structure of most stories in the collection begins with an incident involving a central character that is witnessed by the Buddha Śākyamuni and the monastic sangha. The Buddha then recalls the actions that the main character (or characters) in the opening narrative of the story performed in a previous life that led to the incident followed by the results that they will experience in the future as their actions in the present lifetime come to fruition. In this way, each story in the Karmaśataka becomes a lesson on the workings of karma, which is why the best English translation of the title is most likely One Hundred Lessons on Karma.

The theme of demonic possession occurs relatively rarely in the Karmaśataka, and when it does it is either rejected in favor of a karmic pathology or openly parodied. Of the more than one hundred stories in the collection, roughly six even raise the issue of demonic possession. This alone might tell us something about the relative value that the Buddhist community responsible for compiling the Karmaśataka placed on demonology. This does not mean that the Karmaśataka deviates in any way from presenting a Buddhist worldview that accepts the existence of spirit beings of all kinds. But the text does seem to go out of its way to avoid any narrative that might support the particularly demonic behavior of these spirit beings, and opts instead to focus on karma as the sole determining factor in the circumstances that play out in each story.

Four of the stories that demonstrate the Karmaśataka's rejection of medical demonology in favor of a karmic pathology revolve around abnormalities related to childbirth. The first in this group is "The story of Lake of Jewels" (dbyig mtsho ${ }^{39}$, who, like all of the children in these stories, receives his name because of the strange events surrounding his birth and childhood. The story opens, as so many in the Karmaśataka do, with a newlywed couple that has just conceived a child. In this case,

34 Clearly there were (and are) many Buddhist communities in India and elsewhere that resolved this issue without any real problem. The evidence presented in this study from The Karmaśataka and The Sütra of the Seven Buddhas, however, indicates that the conflicting logics of demonology and karma did not always resolve into such a comfortable syncretism.

35 My work with this text is entirely indebted to the wonderful translation from Dr. Lozang Jamspal and Kaia Tara Fischer, which is forthcoming from the 84,000: Translating the Words of the Buddha project to translate the Tibetan canon. I recently had the privilege of editing a draft translation of the Karmaśataka for this project, and my reflections on the text are a product of that work.

36 (Chutiwongs 1978), p. 139.

37 las brgya tham pa (karmaśataka), Tōh 340, Degé Kangyur 73 (mdo sde, ha), 1.b-309 and Degé kangyur 74 (mdo sde, a), 1.b-128.b.

38 (Yoshimura 1950), p. 142. This is also noted in (Nattier 1991), p. 151.

39 las brgya tham pa, Degé Kangyur 73, 93.a-96.a. 
immediately after the wife has conceived, she is miraculously ornamented with jewelry, parasols and other accoutrements fitting for a celestial palace appear on the roof of the house, and the house itself is constantly strewn with flowers and perfumes. Naturally, the husband wonders if a spirit ('byung po, bhüta) has possessed his wife ${ }^{40}$, so he takes her to a soothsayer who reassures the father-to-be that she is not possessed. Instead, the soothsayer explains, the strange events around her pregnancy are entirely due to the baby in her womb, or, more specifically, to the particular karma that that baby carries with it.

This same narrative pattern is repeated in three more works in the Karmaśataka that open with a pregnancy and childbirth that is accompanied by strange events in the household. In "The Story of Forest Dweller" (dgon pa ba, *āranyaka) ${ }^{41}$, the newly pregnant mother is overcome with the urge to seek out isolated places and is continually unhappy while in the company of others. In both "The Story of Simha" (seng ge $)^{42}$ and "The Story of Jackal" (wa, *jambuka), ${ }^{43}$ the newly pregnant mother begins to smell like feces and is overcome by the urge to eat excrement. In all three cases the father-to-be seeks out a professional opinion to see if his wife has been possessed by a spirit, and in all three cases the soothsayer to whom he brings his wife assures him that it is not demonic possession but the particular being in her womb that is responsible for her abnormal behavioral changes. Most importantly, as the stories of each of these children make clear, the various signs that these concerned fathers read as potential evidence of demonic possession are solely the result of their offspring's particular karma.

There is another set of stories that contain elements related to demonology and demonic possession but fall outside of the grouping in the Karmaśataka that refer to a suspected demonic possession related to conceiving a child. "The Second Story of the Bear" (dom, *bhalluka) ${ }^{44}$ contains a narrative deployment of medical demonology that revolves around a character who has committed an extreme moral and ethical infraction by betraying a bear that offered him shelter from a ravenous lion. After the man betrays the bear, the bear recites a verse lamenting the wicked behavior of immoral beings. Overcome with grief at what he has done, the man then wanders aimlessly repeating the bear's verse until his brothers find him and bring him to a doctor (sman pa, *vaidya) to determine what has driven their brother mad. The doctor informs them that their brother's madness is not a case of spirit possession, and that he cannot heal him. The brothers then take him to a sage (rṣi) who explains that their brother's condition is due to having committed a grave moral misdeed by betraying another living being that had given him shelter. Once again, demonic possession is rejected in favor of karma as the dominant pathology.

These stories speak both to the Karmaśataka's awareness of a system of symptomology for determining demonic possession and to its awareness of a range of specialists who are skilled in the diagnosis and treatment of demonic possession. They also reflect the Karmaśataka's rather dismissive response to such systems of medical demonology. This dismissal can be contrasted with the Âyurvedic literature, in which karma and demonic possession are seen as correlated pathologies that require similar therapeutic methods. It also stands in contrast to the generally affirmative portrayal in the Karmaśataka of medical practices involving the maintenance of proper dietary balance, establishment of proper environmental conditions, and the preparation, prescription, and consumption of medicines. Although there are certain stories in which medical preparations fail in the face of karmic forces, the attitude toward those classical medical sciences that do not deal with the realm of spirit beings is

40 Even though none of the symptoms that prompt suspicion of demonic possession in the Karmaśataka provide an exact match for the symptomologies presented in the bhütavidyā sections of the Caraka, Suśruta, and Aștangahṛdayasamihitās, they do bear some potential correlation to the classes of spirit beings outlined in Āyurvedic demonology. The symptoms presented here seem to combine elements of possession by a celestial class of seizer (graha) such as a deva or gandharva. See (Smith 2006), pp. 488-95.

41 las brgya tham pa, Degé Kangyur 73, 185.a-187.a.

42 las brgya tham pa, Degé Kangyur 73, 193.b-197.a.

43 las brgya tham pa, Degé Kangyur 73, 242.a-248.a.

44 las brgya tham pa, Degé Kangyur 73, 107.a-108.b. 
far more favorable throughout the collection. This indicates that it is not medicine per se but rather medical demonology that is seen as contradictory to the Karmaśataka's central project of teaching about the doctrine of karma in a way that promotes the pursuit of virtue, the abandonment of nonvirtue, and the aspiration to become the disciple of a fully realized Buddha and attain the state of an arhant.

Some might object to this reading of the Karmaśataka's dismissal of medical demonology on grounds that the collection's pattern of invalidating medical demonology is simply a function of its primary purpose, to promote the Buddhist understanding of karma. The Karmaśataka has all of the markings of a composite text, and it is likely that the stories it contains were selected from other compendia based on their coherence around the specific theme of karma. And there is in fact some overlap between the stories in the Karmaśataka and other collections of avadānas. ${ }^{45}$ Furthermore, as a collection of avadānas, a highly narrative-driven genre of Buddhist literature, it may be a bit unreasonable to assume that the narrative devices the authors of these stories apply are anything but that-narrative devices intended only to move the story forward. It is possible to argue that the dismissal of medical demonology in the Karmaśataka is not a reflection of a more general tension among certain Buddhist textual communities between the pathologies of karma and of demonic possession, but simply an unintended byproduct of the literary genre and the specific theme around which these stories are organized. Obviously, a collection of stories whose sole intent is to teach the doctrine of karma is going to privilege the importance of that doctrine in all cases. However, while this is a potentially valid critique of my argument, it still does not account for the fact that the stories in the Karmaśataka demonstrate a bias against medical demonology in all cases while depicting other areas of the medical sciences in a far more positive light. What's more, this same tension between karmic and demonic pathology is evident in the next work this essay examines, The Sütra of the Seven Buddhas.

\section{Buddhist Demonology in The Sūtra of the Seven Buddhas ${ }^{46}$}

The Sūtra of the Seven Buddhas straddles the three literary genres of sütra, dhāranī, and tantra in the Degé Kangyur (sde dge bka' 'gyur). It is listed in the sūtra section of the Dénkarma ${ }^{47}$ and in the dhārañ̄ section of the Pangthangma ('phang thang $m a)^{48}$, which indicates that a Tibetan translation of the text existed by at least the early ninth century. Unfortunately none of the available versions of the text in the Tshal pa and Them spangs ma stemma for the Tibetan Kangyurs contain a colophon, so the precise identity of the translators is unknown. The various Tibetan Translations of the Treatises or Tengyur (bstan 'gyur) do not contain any true commentaries to The Sütra of the Seven Buddhas, but the Degé, Peking (pe cing), and Narthang (snar thang) Tengyurs include a short anonymous work titled Auspicious Verses on the Lineage of the Seven Buddhas (sangs rgyas rabs bdun gyi bkra shis kyi tshigs su bcad pa) ${ }^{49}$ that contains a list of the specific locations and species of tree under which each of the seven buddhas attained awakening. There is a substantial extracanonical Tibetan commentary to the text written by the Bodongpa scholar Choklé Namgyel (Phyogs las rnam rgyal, 1376-1451) titled The General Sūtra Collection Ritual of The Seven Buddhas (sangs rgyas bdun pa'i mdo sde'i cho ga) that consists of instructions for rites that employ the mantras from The Sütra of the Seven Buddhas. ${ }^{50}$

The text was first translated into Chinese in the early half of the sixth century CE, and there are three Chinese translations that preserve separate titles for the text. The sixth century Liáng

45 For a brief explanation of the relationship between the Karmaśataka and the Avadānaśataka, see Nathan Mitchell, "Introduction," The Hundred Deeds (84000: Translating the Words of the Buddha) forthcoming.

46 I am extremely grateful to Ryan Damron and Andreas Doctor of the Dharmachakra Translation Committee for offering their comments and editing expertise on my translation of The Sütra of the Seven Buddhas. I would also like to express my gratitude to the Dharmachakra Translation Committee for funding my translation work on this text. The published translation is forthcoming with 84,000: Translating the Words of the Buddha.

47 (Yoshimura 1950), p. 135.

48 (Bod ljongs rten rdza 2003), p. 25.

49 D 4412; Q 5957; N 4720.

50 Phyogs las rnam rgyal and 'Jigs med 'bangs, sangs rgyas bdun pa'i mdo sde'i cho ga, in gsung 'bum/phyogs las rnam rgyal vol. 22 415-45. (Phyogs las rnam rgyal and 'Jigs med 'bangs 1969-1981). 
translation (T. 1333; c. 502-557 CE), whose translator is unknown, refers to the work as the * Ākāśagarbhapariprcchā-saptabuddha-dhāran̄i-sūtra. ${ }^{51}$ The sixth century Jñānagupta translation (T. 1334; $587 \mathrm{CE})$ refers to the text as the ${ }^{*}$ Tathāgata-upāyakausalya-mantra-sūtra. ${ }^{52}$ The Fa-t'ien translation (T. 1147; 984 CE) refers to the work as the Ārya-Ākāśagarbha-bodhisattva-dhārañi-sūtra. ${ }^{53}$ Like the royal Tibetan catalogues of translated works, the Chinese canon also classifies the text as both sutra and dhārani. The Degé Kangyur expands this dual classification, ${ }^{54}$ including versions of the text in "The Sūtra Collection" (mdo sde), 55 "The Tantra Collection" (rgyud 'bum) ${ }^{56}$, and "The Compendium of Dhāranī" (gzungs 'dus). ${ }^{57}$ Thus like so many works in the Tibetan and Chinese canons, The Sūtra of the Seven Buddhas contains elements associated with a number of different genres of Buddhist literature. This eclecticism explains its dual and tripartite genre classifications. As I argue below, the eclectic style of The Sūtra of the Seven Buddhas—its combination of elements from Mahāyāna sūtra, dhārañi, and kriyātantra literature-allows for a Buddhist medical demonology to emerge in the text.

The Sütra of the Seven Buddhas opens with the Buddha residing in an alpine forest on Mt. Kailāsa when he sees a monk in the forest who has been possessed by a spirit ('byung pos zin) and collapsed to the ground where he lies naked, flailing his arms and wailing to the sky. The bodhisattva Ākāsagarbha, the central interlocutor of the text, also sees the monk and approaches and supplicates Śākyamuni for a spell (vidyāmantra) "that can pacify all manner diseases and exorcize all manner of spirits". ${ }^{58}$ Sākyamuni responds by emanating the following six buddhas, with himself as the seventh:

1. Vipaśyin

2. Śikhin

3. Viśvabhū

4. Krakucchanda

5. Kanakamuni

6. Kāśyapa

7. Śākyamuni

Each of these buddhas proceeds in this order to transmit a spell to Ākāśagarbha along with a number of ritual instructions on how the spell can be used. And each time one of the seven buddhas recites their particular spell, with the exception of Śākyamuni himself, the text reminds us that the purpose of the recitation is "in order to benefit all beings, pacify all manner of illnesses, and exorcize all manner of spirits". ${ }^{59}$

51 Lancaster 2018. The Sanskrit back-translations for these titles are provided from Ronald M. Davidson's study of the text. See (Davidson 2015), p. 149.

52 Lancaster, The Korean Buddhist Canon, http://www.acmuller.net/descriptive_catalogue/files/k0338.html.

53 Lancaster, The Korean Buddhist Canon, http://www.acmuller.net/descriptive_catalogue/files/k1106.html.

54 In the interest of space, the material that I cite from The Sütra of the Seven Buddhas will henceforth only be drawn from the version of the text in the "Tantra Collection" (rgyud 'bum). The variants between all three versions are relatively minor, and there is little need to provide references for all three versions of the text in each note.

55 'phags pa sangs rgyas bdun pa zhes bya ba theg pa chen po'i mdo (Saptabuddhakamahāyānasūtra), Tōh 270, Degé Kangyur 68 (mdo sde, ya), 13b-17b.

56 'phags pa sangs rgyas bdun pa zhes bya ba theg pa chen po'i mdo (Saptabuddhakamahāyānasūtra), Tōh 512, Degé Kangyur 88 (rgyud 'bum, na), 39a-42b.

57 'phags pa sangs rgyas bdun pa zhes bya ba theg pa chen po'i mdo (Saptabuddhakamahāyānasūtra), Tōh 852, Degé Kangyur 100 (gzungs 'dus, e), 65a-68b.

58 sangs rgyas bdun pa, Degé Kangyur 88, 39.a-39.b. Tibetan: de nas bcom ldan 'das la byang chub sems dpa' sems dpa' chen po nam mkha' $i$ snying pos 'di skad ces gsol to//nad thams cad rab tu zhi bar boyid pa dang/'byung po thams cad bzlog pa'i rig sngags bcom ldan 'das kyis bstan du gsol/ Translation: Then the bodhisattva great being Ākāsagarbha asked the Blessed One, "Will the Blessed One please teach a vidyāmantra that can pacify all manner of diseases and exorcize all manner of spirits?"

59 sangs rgyas bdun pa, Degé Kangyur 88, 39.b. Tibetan: sems can thams cad la phan pa'i don dang/nad thams cad rab tu zhi bar bya ba dang/'byung po thams cad bzlog pa'i phyir gsang sngags kyi gzhi 'di dag bka' stsal to/ This is only the first occurrence of this phrase, but it is identical in each instance throughout the text. Readers may notice that I have translated the Tibetan term bzlog pa, possibly a translation of the present participle of the Sanskrit *ni $\sqrt{ }$ vrtt, as "exorcize" in some instances and "ward off" in others. This is a stylistic choice that I base on the context in which the term is used. When the term is used in reference to the frame narrative of the sütra, which marks it as a reference to a monk who is already possessed by a spirit, 
The earliest textual witnesses to the arrangement of buddhas in The Sūtra of the Seven Buddhas for which there exists material evidence is found on a fragmentary birch bark manuscript of The Many Buddhas Sūtra that was composed in the Gāndhārī language and has been radiocarbon dated to the first century BCE. ${ }^{60}$ Other early literary evidence can be found in the various Pāli, Sanskrit, and Chinese recensions of the Mahāvadānasūtra. ${ }^{61}$ The archeological evidence for the cult, however, suggests that it is even older. The earliest iconographic witness to this arrangement of the seven buddhas appears in a series of relief carvings on the outer circumambulatory railing of the Bharhut stūpa. Here, six of the seven buddhas from The Sütra of the Seven Buddhas appear in their aniconic representations as the specific species of tree under which they are said to have attained enlightenment. Each is identified by an accompanying inscription in late second century BCE Brahmi script, providing an approximate date for the early emergence of the cult. ${ }^{62}$ The cult of the seven buddhas later gained widespread popularity beginning in the third century $\mathrm{CE}$, with iconic representations of the seven buddhas appearing at a number of important Buddhist archeological sites such as the Amarāvatī stūpa complex at the eastern edge of the Deccan plateau, the Buddhist cave vihāra complexes of Ajanta, Ellora, and Kanheri in the western Deccan, and as far to the northwest as the Swat Valley. ${ }^{63}$

The most recent and thorough research on this text can be found in Ronald M. Davidson's work on The Sūtra of the Seven Buddhas and its importance to a number of early Chinese dhāraṇ̄ compendia. Davidson argues that the original structure of the cult likely emerged in dialogue with the broader South Asian Brahmanical tradition of Dharmaśāstra literature. In this literature, maintaining caste purity over the course of seven generations through the proper observation of codes governing sexual relationships and the proper performance of rites provided the primary means for substantiating members of the brahmin caste's claim to their status as the premier ritual specialists of the South Asian cultural world. Davidson posits that the cult of the seven buddhas provides a similar seven-generation schema for the teachings of Śākyamuni Buddha and the community of the Buddhist sangha that centers on the pure maintenance and transmission of the prātimokșa vows for seven generations of buddhas. By Davidson's argument, this claim would have served to legitimize the Buddhist sangha as a community of ritual specialists that were just as effective in the performance of rites as their Brahmanical contemporaries. ${ }^{64}$

Davidson's hypothesis regarding the cultural milieu out of which the cult of the seven buddhas emerged adopts an inter-textual methodology that traces the seven buddhas across numerous Buddhist sources. This study, however, focuses on the content of The Sütra of the Seven Buddhas, and the material in this work likely postdates the original cult and its early textual and iconographic witnesses. The issue of central concern in this particular formulation of the cult of the seven buddhas is clearly the development of a Buddhist medical demonology. In fact, at the risk of further complicating already muddled Chinese and Tibetan doxographies, I would argue that The Sütra of the Seven Buddhas is best classified as a Buddhist medical text. More specifically, it is a work of Buddhist medical demonology that combines elements of Mahāyāna devotional literature, instructions for the preparation and prescription of medicinal plants and ointments, and instructions on the use of various spells (termed variously as dhāran̄iss, vidyāmantras, guhyamantras, or simply mantras) to treat a broad range of illnesses and conditions that might lead to an untimely death. This relatively short text also preserves one example of the tension between demonological and karmic pathologies that centers on the issue of whether or not the spells pronounced by each of the seven buddhas to ward off illnesses and exorcize

I tend toward the translation "exorcize." When it is appears in the general instructions from the seven buddhas, I tend toward the more inclusive translation "ward off."

60 For an introduction to the text and translation, see Salomon 2018, pp. 265-93.

61 (Davidson 2015), p. 132.

62 Ibid., 129-30.

63 Ibid., 130-31.

64 Ibid., 133-42. 
all manner of spirit beings can also counteract unnatural death that is the result of karmic obscurations from a past life.

The Tathāgata Vipaśyin's recitation and transmission of his spell to Ākāśagarbha contains the kind of eclectic, genre-blending material that begins to explain why The Sütra of the Seven Buddhas can straddle three separate literary genres in the Degé Kangyur. It also gives the reader a first glimpse at just why this work might also be classified as a text on Buddhist medical demonology. The passage reads as follows:

The Tathāgata Vipaśyin hovered in the sky above them and spoke these root verses of the secret mantra in order to benefit all beings, pacify all manner of illnesses, and exorcize all manner of spirits:

namo buddhāya namo dharmāya namah sañghāya

tadyathā ọ̣ hala hala hili hilāya

namo jaga namaśca nāya namo namah svāhā 65

The Tathāgata Vipaśyin addressed the bodhisattva great being Ākāśagarbha, “Ākāśagarbha, whomever bears this vidyāmantra in mind, recites it, or masters it will not be slain by a weapon, nor will they die from drowning, fire, ${ }^{66}$ or a painful illness. They will not suffer an unnatural death, even if they consume poisonous food.

If you recite the vidyāmantra seven times over your food and drink before consuming it, no one else can harm you, you will not contract any illnesses, you will live for a long time, understand what you have studied, and have a vision of the seven tathāgatas.

Recite this vidyāmantra in the ear of someone who has been wounded with a weapon and anoint them with jasmine oil incanted with the vidyāmantra. If you anoint those who are afflicted with diseases such as leprosy or tumors with incanted oil that contains a mixture of jasmine, blue lotus, dill, and wild asparagus, they will recover from all of their illnesses. This mantra can be used for all rites. 67

Several elements in this passage that are common to Mahāyāna sūtra, dhāraṇī, and kriyātantra literature should be immediately apparent to readers who are familiar with these genres of Buddhist scripture. First, there is the spell itself, which clearly qualifies the passage as an example of the dhärani genre. Then there are the various uses of the spell, which begin with averting a short list of untimely deaths (dus ma yin pa' $i$ 'chi ba, *akälamarana) that incorporates some of the standard perilous situations ('jigs $p a$, bhaya) from which bodhisattvas commonly vow to rescue living beings who recite or recollect their names in the Mahāyāna sūtras, particularly in the sub-genre of bodhisattva aspiration (smon lam, pranidhāna) literature. Elements of the dhārañ genre such as understanding everything one has studied

65 Tentative English translation: Homage to the Buddha. Homage to the Dharma. Homage to the Sangha. Tadyathā om hala hala hili hili hilāya. Homage to the world, and homage to the guide. Homage to you, svāhā.

66 The Tibetan for fire $(m e)$ is omitted, likely in error, in Tōh 270.

67 sangs rgyas bdun pa, Degé Kangyur 88, 39.b. Tibetan:/na mo bud+d+hA ya/na mo d+harmA ya/na maH saM g+hA ya/tad+ya thA/oM ha la ha la/hi la hi lA ya/na mo dza ga na mi tsa nA ya/na mo na maH swA hA/de nas de bzhin gshegs pa rnam par gzigs kyis byang chub sems dpa' sems dpa' chen po nam mkha'i snying po la 'di skad ces bka' stsal to//nam mkha'i snying po gang la la zhig rig sngags 'di 'chang ngam/klog gam/kun chub par byed na/de'i lus la mtshon gyis mi tshugs/chu dang me'i sdug bsngal ba'i nad kyis 'chi ba'i dus byed par mi 'gyur ro//dus ma yin pa'i 'chi bas 'chi ba'i dus byed par mi 'gyur ro//de dug zos kyang zas bzhin du 'gyur ro//zas dang skom la lan bdun bzlas brjod byas te zos na pha rol gyi gnod pa mi 'byung ngo//nad thams cad kyis btab par mi 'gyur ro//ring du 'tsho bar' gyur ro//thos pa 'dzin par 'gyur ro//de bzhin gshegs pa bdun gyi gzugs mthong bar'gyur ro//mtshon btab pa'i rna bar bzlas brjod byas la sna ma'i mar sbyin no//mdze dang skrangs nad kyis btab pa rnams la sna ma'i mar dang/ut+pa la sngon po dang/shu ti dang/nye'u shing pa rnams bsres pa'i mar byin na nad thams cad sos par'gyur ro//las thams cad la yang sbyar bar bya'o/. 
are evoked again in the second list of benefits to reciting the spell, but here the spell is not just recited, it is recited over food and drink and essentially consumed. Finally, an element that is common to the kriyātantra emerges in the last line of this section where the Tathāgata Vipaśyin assures Ākāśagarbha that, in addition to the list of applications he has just listed, his spell "can be used for all rites" (las thams cad la yang sbyar bar bya'o). This phrase signals the kind of ritual eclecticism that Phyllis Granoff has pointed to in one of the most important works of the Buddhist kriyātantra genre, the Mañjuśrimmūlakalpa, which contains numerous instances in which the single-syllable (ekākșara) mantra is similarly argued to render all Buddhist (lokottara) and non-Buddhist (laukika) rituals effective. ${ }^{68}$ Finally, the medical applications of the Tathāgata Vipaśyin's spell are quite clear in the passage, which contains one recipe for a medicinal oil that is both incanted with the spell and infused with a number of plants with known medical properties.

Explicit evidence of a Buddhist medical demonology is strangely absent from the Tathātaga Vipaśyin's instructions for using his spell, despite the fact that the frame narrative for the text establishes that the primary reason that Śākyamuni has emanated as the seven buddhas reasons is to provide the bodhisattva Ākāśagarbha with a spell for exorcizing spirits. Buddhist medical demonology is on prominent display, however, in the next passage from The Sütra of the Seven Buddhas, which contains the Tathāgata Śikhin's spell and related instructions. The passage reads as follows:

Then the Tathāgata Śikhin hovered in the sky above them and spoke these root verses of the secret mantra in order to benefit all beings, pacify all manner of illnesses, and exorcize all manner of spirits:

namo buddhāya namo dharmāya namah sanghhāya

oṃ paca paca pācaya pācaya sarvabhūtānām

chindaya kīlaya paravidyānām svāhā 69

Ākāsagarbha, I and millions of Buddhas have taught this secret mantra in order to benefit all beings, to completely pacify all manner of illnesses, to ward off spirits that harm one's meditation and cause nightmares, and to prevent untimely death. Now you must uphold it.

Ākaśagarbha, if someone focuses on my heart mantra three times a day, they will not be harmed by others, they will meet the Tathāgata in their dreams, and they will not suffer a horrible death. When they die, they will meet with the tathāgatas and serve them.

You can also use the rite to bind the patient with a protection cord against all manner of illnesses. In cases where an illness is the result of a humoral imbalance, you can incant jasmine oil with the mantra and give it to the patient. You can perform the rite of sealing off the directions with water incanted with the mantra, and you can use an incanted cord to protect yourself. You can tie a blue protection cord incanted with the mantra on a child to guard against seizers that possess children. You can whisper the mantra seven times in the ear of someone who has been struck down with a weapon, and you can use it to control others with your mind. ${ }^{70}$

68 Granoff argues that the Mañjuśrimmūlakalpa employs the categories of laukika and lokottara specifically to mean non-Buddhist and Buddhist traditions. (Granoff 2000).

69 Tentative English translation: Homage to the Buddha. Homage to the Dharma. Homage to the Sarigha. Om cook cook, cook them out* cook out all the spirits. Pierce and pin down the enemy's vidyā beings svāhā. *I've chosen the phrase "cook them out" for the 2p. sing. causative imperative of $\sqrt{ }$ pac instead of the more literal "cause them to be cooked".

70 sangs rgyas bdun pa, Degé Kangyur 88, 39.b-40.a. Tibetan:/de nas de bzhin gshegs pa gtsug tor can steng gi nam mkha' la bzhugs te/sems can thams cad la phan pa'i don dang/nad thams cad rab tu zhi bar bya ba dang/'byung po thams cad bzlog pa'i phyir gsang sngags kyi gzhi 'di dag bka' stsal to//na mo bud+d+hA ya/na mo d+harmA ya/na maH saM g+hA 
This passage contains a number of references that signal the emergence of a Buddhist medical demonology blending elements from the Mahāyāna sūtra, dhāraṇ̄, and kriyātantra literature. The applications of the Tathāgata Śikhin's spell quickly move from using the spell as part of a meditation practice that results in communion with the tathāgatas to a list of medical applications covering everything from illnesses that result from humoral imbalance ('dus pa las gyur pa, *sāmnipātika) to the important demonological medical practice of protecting against the various classes of seizers that specifically target children (byis pa rnams kyi gdon, *ballagraha). Then, in its final instruction, the text strays into the territory of kriyātantra applications of mantras for rites that are used to control a particular target. Commonly termed controlling rites (dbang, vaśya), this application of mantra recitation is part of a broader, loosely standardized set of practical applications of ritual that can be found throughout the kriyatantra literature. ${ }^{71}$

The clearest indication that the Tathāgata Sikhin's instructions in The Sūtra of the Seven Buddhas express a form of Buddhist medical demonology is the spell itself, which makes explicit reference to its own medical demonological applications. Following the initial invocation to the three jewels, the spell proper, in a style common to nearly all mantras and dhāraniss, contains a handful of imperative forms that function as direct instructions for the deity that has been invoked, in this case the Tathāgata Śikhin. The instructions to "cook" (paca) and "cook out" (pācaya) all spirits (sarvabhütānām) are a direct reference to performing an exorcism for someone who is possessed by a demonic being. A similar use of the term appears in the Śaiva Kriyākālagunottara's ritual instructions for the deity Garuda's vipati mantra, which remains in active use to this day among modern Śaiva, Vaiṣnava, and Vajrayāna communities. ${ }^{72}$ The spell then makes specific reference to a phenomenon I have noted elsewhere as an important factor in the emergence of a Buddhist demonology - the weaponization of spells and mantras and the formulation of ritual means to protect against such weaponization. Here the Tathāgata Śikhin has augmented his own spell for exorcizing spirits with a second spell for neutralizing an enemy's spells/vidyā beings (paravidyānām ).

Participation in the broader South Asian culture of weaponized ritual was undoubtedly one of several important factors that contributed to the ritual theories and praxes that emerge in early Buddhist esoteric literature. The overlap between this phenomenon and the emergence of a Buddhist medical demonology is evident in none other than the Bhaișajyagurusūtra. ${ }^{73}$ Unfortunately, just as demonology has been marginalized in the field of Buddhist studies, its sub-field of Buddhist medicine, and in the study of Âyurveda, the culture of weaponized ritual that played such a critical role in the emergence of esoteric Buddhism, particularly in the kriyatantra literature, remains sorely understudied. The kriyātantra literature contains a wealth of data proving that Buddhist ritual specialists were just as

ya/oM pa tsa pa tsa pA tsa ya pA tsa ya/sarba b+hU tA nAM/ts+tshin+d+ha ya/kI la ya/ba ra bid+yA nAM swA hA/nam mkha'i snying po sems can thams cad la phan pa'i don dang/nad thams cad rab tu zhi bar bya ba dang/bsgom nyes pa dang/rmi lam ngan pa thams cad bzlog pa dang/dus ma yin par 'chi ba dgag pa'i phyir sangs rgyas bye ba khrag khrig brgya stong phrag du mas gsungs shing ngas kyang da ltar bshad pa'i snying po 'di zung shig nam mkha'i snying po gang la la zhig nga'i snying po 'di nyin lan gsum yid la byed na/de la pha rol gyi gnod pa 'byung bar mi 'gyur ro//gnyid kyis log pa'i rmi lam na de bzhin gshegs pa'i gzugs mthong bar 'gyur ro//gshis ngan du 'chi bar mi 'gyur ro//'di nas shi 'phos nas de bzhin gshegs pa dang phrad par 'gyur zhing mnyes par byed par 'gyur ro//de nas 'di'i cho ga gzhan ni nad thams cad la skud pas bcing bar bya'o//'dus pa las gyur pa la sna ma'i mar la bzlas brjod byas te sbyin no//chus phyogs bcing bar bya'o//skud pas bdag bsrung ngo//byis pa rnams kyi gdon dag la skud pa sngon po gdags so//mtshon btab pa'i rna bar lan bdun bzlas brjod bya'o/ / gzhan dag la yang rang gi blos sbyar bar bya'o/.

71 Despite their widespread occurrence in later Indian and Tibetan esoteric traditions, the set of four "karmas" or "ritual actions" of pacifying (zhi ba, śāntika), increasing (rgyas pa, pauștika), attracting (dgug pa, ākarșana), and subjugating (mngon spyod, abhicāruka) does not represent the full range of practical purposes toward which Buddhist esoteric ritual specialists directed their rites. In reality, the lists of various ends to which a ritual might be directed in the kriyatantra literature demonstrate a far greater degree of variability and diversity than the more standard and familiar list of four. This phenomenon is similar to the wide variation in the various supernatural powers ( $g r u b p a$, siddhi) that one gains from the performance of ritual, which were increasingly systematized into a sets of eight as Vajrayāna Buddhist textual traditions underwent a number of phases of systematization both in India and elsewhere.

72 Slouber (2012), pp. 90-91. Slouber's translation of the Kriyākālagunottara's instructions on this mantra term read, "he should say 'Burn! Cook!' in this way. He would be able to purify one afflicted by demons, fever, or poison." See (Slouber 2012 ), p. 99.

73 (Krug 2018), pp. 61-62. 
interested in acting as aggressors as they were in defending themselves or their patrons from attack both from both the physical and demonic weapons of their enemies. Rituals in this literature for controlling various classes of spirit deities or inflicting harm on one's enemies through the use of mantras, mudrās, and mandalas are often aimed at enlisting various Buddhist deities and non-Buddhist spirit beings to carry out the task.

The set of instructions that the Tathāgata Viśvabhū provides for his spell contains an example of how Buddhist demonology can be both weaponized and used for medical purposes. It also contains the single instance in The Sütra of the Seven Buddhas in which the tension between karmic and demonic pathologies is clearly on display. The passage reads as follows:

Then the Tathāgata Viśvabhū hovered in the sky above them and spoke these root verses of the secret mantra in order to benefit all beings, pacify all manner of illnesses, and exorcize all manner of spirits:

namo buddhāya namo dharmāya namah sañghāya

ọ̣ kala kala kili kili kulu kulu kulotsādanạ̣ ${ }^{74}$ kuru sarvagrahāṇām svāhā $\bar{a}^{75}$

$\bar{A}$ kāsagarbha, these root verses of the secret mantra are taught by all of the past, future, and present tathāgatas of the fortunate eon, and now I have spoken them as well. Ākāśagarbha, you must uphold these root verses of the secret mantra.

If someone bears in mind, recites, or masters them, they will not be harmed with a weapon, affected by poison, affected by poisonous brews, or infected with plague. They will not drown, die of unnatural causes, or suffer a lowly death unless these are karmic obscurations that result from a previous lifetime. Any monk, nun, or lay person who rises in the morning, washes their head, and recites this secret mantra 108 times before an image of the Tathāgata will be able to purify all of their karmic obscurations.

Once the dhāraṇi has been spoken to any hostile beings or kings, you will have power over all of them. You will master all fears. Wearing a white protection cord incanted with the mantra will guard against all manner of quarrelsome men and women as well as any argument and dispute. An incanted protection cord made with fiber from a date tree can be used against diseases of the eye and hung on one's ear.

To paralyze an army, perform a fire offering one hundred and eight times with incanted popped rice that has been soaked in yogurt and honey while reciting the following mantra each time:

rājanām ${ }^{76}$ rājāmātram vā vaśi karotu ${ }^{77}$ kāmena ${ }^{78}$

74 kulotsādanaṃ] S; kula udsadhanaṃ] D 270; kulotsādhanānāṃ] D 512; kulotsādhanānāṃ] D 852. The Stok Palace Kangyur contains the only truly viable transliteration of the Sanskrit, so the transliteration and translation of this mantra follows the Stok Kangyur. See 'phags pa sangs rgyas bdun pa zhes bya ba theg pa chen po'i mdo (Āryasaptabuddhakan nāma mahāyānasūtra) S 472 Stok Palace Kangyur 102 (rgyud, da), 17b.

75 Tentative English translation: Homage to the Buddha. Homage to the Dharma. Homage to the Sañgha. Om kala kala kili kili kulu kulu destroy the clans of all seizers svāhā.

76 rājanām $m$ ] D 270; rājānām and thus means 'belonging to a king.' Here the term might be in the feminine singular accusative to signify the queen, or perhaps in a masculine plural accusative in which the nasal has been transcribed as anusvara. The context for the mantra and the inclusion of the phrase "or just the king" (rājāmātram vōa) indicates that the term rājanām is likely meant here to signify the king's army.

77 vaśikarotu] D 270; vaśikaratu] D 512; D 852; vāśikāratu] S. The transliteration preserved in D 270 is the proper imperative 3p. sing. imp. form of $k r$.

78 Tentative English translation: Bend the king's army or just the king to my will svāhā. 
To purify all your own and all beings' obscurations and misdeeds and to obtain great prosperity and wealth, recite the dhāranī while offering sesame seeds one thousand times into a fire alter that has been kindled with date palm branches. ${ }^{79}$

To purify all your misdeeds, master all vidyämantras, or to ritually cleanse yourself you should wash with dill, spikenard, ${ }^{80}$ foxtail millet, sirisa, valerian, saffron, nut grass, bitter gourd, bodhi tree, and mango flowers. ${ }^{81} \mathrm{Next}$, fast for an entire day in front of a Buddha image, and then place these ingredients in a fresh vase. On the full moon, bathe in front of an image of the Buddha while reciting the heart mantra one thousand and eight times.

To neutralize poison, sit before an image of the Buddha and use a ladle made of teak to offer cow dung ${ }^{82}$ onto a ritual fire while reciting the victim's name one hundred and eight times. The poison will then be neutralized. This mantra protects one from seizers ${ }^{83}$ and works for any rite related to spirits and the like. It will pacify them. ${ }^{84}$

The demonological orientation of the Viśvabhū's spell is clear in its concluding imperative phrase "destroy the clans of all the seizers" (kulotsādanam kuru sarvagrahānām), but as with the Tathāgata Sikhin's spell, its applications represent a range of apotropaic and soteriological concerns.

Viśvabhū's spell and instructions also provide some interesting insights regarding the tension between Buddhist medical pathologies that stress the primacy of the doctrine of karma and those that offer more apotropaic solutions to averting disaster, curing illness, and exorcizing or repelling spirit beings. The line in this excerpt that reads "[t]hey will not drown, die of unnatural causes, or suffer

79 D 270 and D 512 repeat the line 'o ma can gyi shing gi sbar shing gis me bus la bsreg bya til dag lan stong sbyin sreg bya'o. It has only been rendered once in translation.

80 na la da] D 270; na la] D 512; D 852. This translation follows D 270. Nalada is a medicinal plant that is attested in the Atharvaveda and Suśrutasamhitā.

81 a mra'i mgo lcogs] D 270; a mra'i mgo thogs] D 512; D 852. This translation follows D 270, which is a Tibetan translation of the Sanskrit āmrastabaka.

82 seng ldeng gi thur ma ba'i lci bar smyugs] D; seng ldeng gi phur ma spyi bor bsnyugs S.

83 gdon bsrung ba dang/'byung po la sogs pa'i] D 270; gdon dang/srung ba dang/'byung po la sogs pa'i] D 512; gdon dang srung ba dang 'byung po la sogs pa'i] D 852; gdon dang/bsrung ba dang/'byung po la sogs pa'i] S. This translation follows D 270 . The variants in D 512 and D 852 suggest that the term srung ba was read as another class of being in series with the terms gdon (graha) and 'byung po (bhīta). This is taken as a scribal error based on lack of evidence for any class of being translated into Tibetan as srung $b a$. The Tathāgata Viśvabhū's mantra is also explicitly directed at grahas. It is also possible to read the phrase gdon bsrung ba as graharakșa, which could refer to an amulet used to protect one from grahas. The translation here remains ambiguous on this point to allow for this interpretation.

84 sangs rgyas bdun pa, Degé Kangyur 88, 40.b-41.a. Tibetan:/de nas de bzhin gshegs pa thams cad skyob steng gi nam mkha' la bzhugs te/sems can thams cad la phan pa'i don dang nad thams cad rab tu zhi bar bya ba dang/'byung po thams cad bzlog pa'i phyir gsang sngags kyi gzhi 'di dag bka' stsal to//na mo bud+d+hA ya/na mo d+harmA ya/na maH saM g+hA ya/oM ka la ka la/ki li ki li/ku lu ku lu/ku lo ta sA d+ha nA nAM/ku ru sarba gra hA NAM swA hA/nam mkha'i snying po gsang sngags kyi gzhi 'di dag ni bskal pa bzang po'i de bzhin gshegs pa 'das pa dang/ma byon pa dang/da ltar byung ba thams cad kyis gsungs shing ngas kyang da ltar bshad pa ste/nam mkha'i snying po khyod kyis gsang sngags kyi gzhi 'di dag zung shig/gang la la zhig 'dzin tam/klog gam/kun chub par byed na de'i lus la mtshon gyis mi tshugs/dug gis mi tshugs/dbyig dug gis mi tshugs/rims nad kyis mi 'debs shing/chu dang/dus ma yin par'chi ba dang/gshis ngan du 'chi bar mi 'gyur te/sngon gyi las kyi sgrib pa rnams ni ma gtogs so/dge slong ngam dge slong ma'am dge bsnyen nam/dge bsnyen ma gang la la zhig nang par langs nas mgo bkrus te/de bzhin gshegs pa'i spyan sngar lan brgya rtsa brgyad brjod na/de'i las kyi sgrib pa thams cad byang bar 'gyur ro//de la sems can sdang ba gang dag rgyal po rnams thog mar smra bar 'gyur ro//sems can thams cad de'i dbang du 'gyur ro//'jigs pa thams cad kyi nang du yid la bya'o//'thab pa dang/'thab me dang/rtsod pa dang/'gyed pa thams cad du skud pa dkar po gdags so//mig nad la shing 'o ma can las skud pa byas te rna ba la gdags so//dmag rengs par byed par 'dod pas zho dang/sbrang rtsi la btags pa'i 'bras yos la lan brgya rtsa brgyad sbyin sreg bya'o//rA dzA nAM rA dzA mA tram+bA ba shI ka ra tu kA me na/'o ma can gyi shing gi sbar shing gis me bus la bsreg bya til dag lan stong sbyin sreg bya'o//bdag dang sems can thams cad kyi sgrib pa thams cad dang/sdig pa sbyang zhing dpal chen po dang/nor gyi phung po chen po bsgrub par 'dod na 'o ma can gyi shing gi sbar shing gis me bus la bsreg bya til dag lan stong sbyin sreg bya'o//sdig pa ji snyed pa thams cad sbyang bar 'dod pa dang/rig sngags thams cad 'grub par'dod pa dang/bdag bkru bar'dod pas shu ti dang/na la dang/khre dang/shi ri sha dang/rgya spos dang/gur gum dang/gla sgang dang/in dra ba ru na dang/byang chub kyi shing dang/a mra'i mgo thogs dang/'di rnams kyis bkru bar bya ste/sangs rgyas kyi spyan sngar nyin zhag gcig smyung ba bya zhing bum pa sar pa bzhag ste/zla ba nya la sangs rgyas kyi gzugs kyi spyan sngar snying pos lan stong rtsa brgyad bsngags la khrus bya'o//dug mi gdug par byed par 'dod pas sangs rgyas kyi spyan sngar seng ldeng gi thur ma ba'i lci bar smyugs pa brgya rtsa brgyad ming nas smos te sbyin sreg byas na dug mi gdug par 'gyur ro//gdon dang/srung ba dang/'byung po la sogs pa'i las thams cad la yang sbyar bar byas na bde bar gnas par' gyur ro/. 
a lowly death unless these are karmic obscurations that result from a previous lifetime", ${ }^{85}$ perfectly captures the rupture that occurred in Buddhist ritual theory as Buddhists developed and implemented their own form of medical demonology. The line seems entirely out of place within the text, and one strains to understand precisely why, in this case, the spell will not prevent the unwanted results of one's past karmic obscurations from coming to fruition. This dissonance is even more pronounced given that the very next line provides ritual instructions on how to use the spell to purify one's karmic obscurations. To make matters more confusing, two more sets of instructions on how to use the spell to purify one's own and others' karmic obscurations and misdeeds appear just a few more lines down in the text. Finally, a very similar line appears in the instructions for using the Tathāgata Kanakamuni's spell with no mention of the spell not working if the subject's unnatural death is due to karmic obscurations from a previous life. ${ }^{86}$ The issue cannot be completely resolved based on the information provided in the text alone. It is possible, for instance, that the intended meaning of Viśvabhū's instructions is that his spell can purify any karmic obscurations and misdeeds that have been generated in this life, but not those from a past life. But this falls short of a truly convincing resolution to the problem - after all, a karmic obscuration is the roughly the same whether or not it results from the current or a past life, and as long as it has not yet come to fruition, it should be subject to the same rules of potential expiation.

Even if there is some resolution to the issue, as I am sure an emic commentator invested in resolving the problem could no doubt find, it is far more productive for the purpose of this study to preserve the tension that this line introduces to the text. Here, we have a set of instructions for using a spell for eliminating all of the classes of seizers (graha), the same demonic, disease causing beings with which Āyurvedic demonology is concerned, that places a limit on the efficacy of demonological means for preventing unnatural death. That limitation, the line that this text (at least in this instance) draws around the efficacy of its own medical demonology, outlines the contours of the tension between karmic and demonic pathology. Thus, while The Sütra of the Seven Buddhas is a work that is overwhelmingly in favor of promoting a system of Buddhist medical demonology, in this one instance it seems that its compiler, author, or perhaps some other party ${ }^{87}$ expresses some hesitation around allowing that system to completely undermine the logic of the Buddhist doctrine of karma.

The remaining sets of instructions in The Sūtra of the Seven Buddhas from the tathāgatas Krakucchanda, Kanakamuni, Kāśyapa, and Śākyamuni contain the same blending of elements from the Mahāyāna sūtra, dhāraṇi, and kriyātantra literature to produce what I have argued here essentially constitutes a text on Buddhist medical demonology. It should be noted, however, that while the instructions for each of these tathāgatas' spells contain applications for warding off or curing illnesses brought on by demonic possession, the spells themselves do not contain any imperative phrases that explicitly mention the subjugation or destruction of various classes of known demonic beings. ${ }^{88}$

85 sangs rgyas bdun pa, Degé Kangyur 88, 40.b. Tibetan: chu dang/dus ma yin par 'chi ba dang/gshis ngan du 'chi bar mi 'gyur te/sngon gyi las kyi sgrib pa rnams ni ma gtogs so/.

86 Sangs rgyas bdun pa, Degé Kangyur 88, 41.b. Tibetan: /nam mkha'i snying po gang la la zhig snying po 'di 'dzin cing rtag tu bzlas brjod byed pa de la mtshon gyis 'jigs pa mi 'byung/me dang/chu dang/lce 'bab pas 'chi ba'i dus byed par mi 'gyur/dug thams cad kyang zas dang 'dra bar thub par 'gyur/dus ma yin par' chi bas 'chi ba'i dus byed par mi 'gyur/gshis ngan du 'chi bar mi 'gyur/tshe ring bar 'gyur/longs spyod che bar 'gyur/ Translation: Ākāśagarbha, whoever upholds this heart mantra and continuously recites it will not fear any weapon, nor will they die from fire, drowning, or lightning. They will be able to consume poisons as easily as food. They will not suffer an unnatural death or suffer a lowly death. They will have a long life and be extremely prosperous.

87 It is possible, for instance, that this line is an example of a note that later found its way into the body of the text itself. It is purely speculative to say so, but it is possible given the fact that the line represents such a stark deviation from the text.

88 I say this with the following word of caution. The remaining spells in this text do contain quite a few terms that I have not been able to identify as Sanskrit names for known demonic beings. This does not mean, however, that they are necessarily absent from the mantras. It is entirely possible that there may be non-Sanskritic terms in the mantras that, if we had some means of correctly interpreting them, would reveal themselves to be the names of various classes of demonic beings. 


\section{Conclusions: Buddhist Demonology is Buddhist Medicine}

In this essay, I have highlighted the deficit of scholarship in the field of Buddhist studies, particularly among scholars of Indian Buddhist traditions, that pays serious attention to the impact of Buddhist traditions' dialogical relationships with localized popular religious cults. I have pointed to the fact that, as a result of this deficit, very little serious attention has been given to the development of Indian Buddhist systems of demonology. I have also argued that the same situation applies to the modern academic study of Āyurvedic demonology. The reasons underlying just why scholars have marginalized such a critical aspect of these traditions are no doubt numerous, but I have suggested that in the context of Buddhist Studies the perpetuation of this lacunae is an outgrowth of an overt bias against Buddhist demonology established early in the field's history combined with a lack of effort on the part of contemporary scholars to adopt a truly affirmative revaluation of this pervasive feature of Indian Buddhist traditions. This is symptomatic of a larger problem in the Human Sciences, which promote hermeneutic systems founded upon the broad-reaching fallacy of what Josephson-Storm so skillfully identifies as "the myth of disenchantment."

In response to this problem, I suggest the following two arguments that affirm the importance of demonology as a subject of study. First, in traditional South Asian medicine, demonology is a viable medical science, complete with its own advanced systems of symptomology, diagnosis, and treatment. Presentations of traditional South Asian medical systems such as Ayurveda that ignore this fact misrepresent their own subject of study. Second, Buddhist demonology is likewise a legitimate branch of South Asian Buddhist medicine that is worthy of serious scholarly inquiry and study. The devaluation of systems Buddhist demonology as a field of study is particularly pronounced in the study of Indian Buddhist traditions. Buddhist studies scholars who work with Chinese, Japanese, Tibetan, and Korean Buddhist traditions, and those who work within these cultural-geographic regions on the subfield of Buddhist medicine, demonstrate far greater sophistication in their approach to the dialogical assimilation and synthesis of local spirit religions and Buddhist systems of demonology. Those of us who focus on Indian Buddhist traditions could learn a great deal from their example.

The essay then explored possible evidence for an emic bias among Indian Buddhist traditions against fully integrating elements from localized popular religious cults of various spirit beings and their demonologies into Buddhist doctrine. Here I presented a number of examples from the Karmaśataka, a collection of avadānas organized around the central theme of karma that dates from the first century CE and likely preserves material that is much older. The Karmaśataka takes a rather dismissive approach to the issue of demonic possession in favor of presenting karma as the sole viable explanation for the various illnesses and afflictions that beings endure. The dismissal of demonic possession in the Karmaśataka indicates that, at least for some Indian Buddhist textual communities, the development of a Buddhist demonology may have been seen as a disruption or contradiction of one of the tradition's central and defining doctrines.

Finally, the essay examined The Sütra of the Seven Buddhas, a text that I argue exhibits all of the characteristics of a Buddhist medical demonology. This work's combination of elements from Mahāyāna sūtra, dhāraṇī, and kriyātantra literature led Chinese and Tibetan doxographers to locate it in both the sūtra and dhārañ̄ sections of their respective canons and, in the case of the Degé Kangyur, among the sūtra, tantra, and dhārañi sections. This blending of Buddhist literary genres in The Sütra of the Seven Buddhas and the text's own statements that its spells are effective for all rites provides some preliminary evidence of a correlation between Buddhist medical demonology and the culture of ritual eclecticism that characterizes the Buddhist kriyātantra literature.

Funding: This research received no external funding.

Conflicts of Interest: The author declares no conflicts of interest. 


\section{References}

\section{Primary Sources}

las brgya tham pa (Karmaśataka). Tōh 340 Degé Kangyur 73, 1.b-309. mdo sde, ha; and Degé Kangyur 74, 1.b-128.b. mdo sde, a.

'phags pa sangs rgyas bdun pa zhes bya ba theg pa chen po'i mdo (Saptabuddhakamahāyānasūtra). Tōh 270, Degé Kangyur $68,13 b-17 b$. mdo sde, ya.

'phags pa sangs royas bdun pa zhes bya ba theg pa chen po'i mdo (Saptabuddhakamahāyānasūtra), Tōh 512, Degé Kangyur $88,39 a-42 b$. rgyud 'bum, na.

'phags pa sangs royas bdun pa zhes bya ba theg pa chen po'i mdo (Saptabuddhakamahāyānasūtra), Tōh 852, Degé Kangyur $100,65 \mathrm{a}-68 \mathrm{~b}$. gzungs 'dus, e.

'phags pa sangs rgyas bdun pa zhes bya ba theg pa chen po'i mdo (Āryasaptabuddhakan nāma mahāyānasūtra) S 472 Stok Palace Kangyur 102, 15b-21b. rgyud, da.

\section{Secondary Sources}

Bod ljongs rten rdza, ed. 2003. Dkar chag 'phang thang ma. sgra sbyor bam po gnyis pa. Pe cin: Mi rigs dpe skrun khang.

Cantwell, Cathy, and Robert Mayer. 2010. Continuity and Change in Tibetan Mahāyoga Ritual. In Tibetan Ritual. Edited by José Ignacio Cabezón. New York: Oxford University Press, pp. 69-88.

Chutiwongs, Nandana. 1978. On the Jātaka reliefs at Cula Pathon Cetiya. Journal of the Siam Society 66: 133-51.

Cohen, Richard S. 1998. Nāga Yakṣin̄ī, Buddha: Local Deities and Local Buddhism at Ajanta. History of Religions 37: 360-400. [CrossRef]

Davidson, Ronald M. 2015. Studies in Dhāraṇī III: Seeking the Parameters of a Dhāraṇī-pițaka, the Formation of the Dhārañisamgrahas, and the Place of the Seven Buddhas. In Scripture: Canon: Text: Context: Essays Honoring Lewis Lancaster. Edited by Richard K. Payne. Berkeley: Institute of Buddhist Studies and BDK America, Incorporated, pp. 119-80.

Decaroli, Robert. 2004. Haunting the Buddha: Indian Popular Religions and the Formation of Buddhism. New York: Oxford University Press.

Demiéville, Paul. 1985. Buddhism and Healing: Demiéville's Article "Byō" from Hobogirin. Translated by Mark Tatz. Lanham: University Press of America, Inc.

Fiordalis, David. 2018. Medical Practice as Wrong Livelihood: Selections from the Pāli Discourses, Vinaya, and Commentaries. In Buddhism and Medicine: An Anthology of Premodern Sources. Edited by C. Pierce Salguero. New York: Columbia University Press, pp. 105-12.

Gethin, Rupert. 1998. The Foundations of Buddhism. New York: Oxford University Press.

Granoff, Phyllis. 2000. Other People's Rituals: Ritual Ecclecticism in Early Medieval Indian Religion. Journal of Indian Philosphy 28: 399-424.

Josephson-Storm, Jason Ā. 2017. The Myth of Disenchantment: Magic, Modernity, and the Birth of the Human Sciences. Chicago: The University of Chicago Press.

Karmay, Samten G. 1998. The Arrow and the Spindle: Studies in History, Myths, Rituals, and Beliefs in Tibet. Kathmandu: Mandala Book Point, vol. I.

Krug, Adam C. 2018. The Seven Siddhi Texts: The Oḍiyāna Mahāmudrā Lineage in its Indic and Tibetan Contexts. Ph.D. Thesis, University of California, Santa Barbara. ProQuest 10830389.

Lancaster, Lewis R. 2018. The Korean Buddhist Canon: A Descriptive Catalogue. Available online: http://www. acmuller.net/descriptive_catalogue/files/k0346.html (accessed on 14 November 2018).

Mitchell, Nathan. forthcoming. "Introduction," The Hundred Deeds. Online at 84000: Translating the Words of the Buddha.

Nattier, Jan. 1991. Once Upon a Future Time: Studies in a Buddhist Prophecy of Decline. Berkeley: Asian Humanities Press.

Phyogs las rnam rgyal and 'Jigs med 'bangs. 1969-1981. sangs rgyas bdun pa'i mdo sde'i cho ga. In gsung 'bum/phyogs las rnam rgyal. New Delhi: Tibet House, vol. 22, pp. 415-45.

Salguero, C. Pierce, ed. 2018. Buddhism and Medicine: An Anthology of Premodern Sources. New York: Columbia University Press. 
Salomon, Richard. 2018. The Buddhist Literature of Ancient Gandhära: An Introduction with Selected Translations. Somerville: Wisdom Publications, Inc.

Slouber, Michael James. 2012. Gāruḍa Medicine: A History of Snakebite and Religious healing in South Asia. Ph.D. dissertation, University of California, Berkeley, CA, USA.

Smith, Frederick M. 2006. The Self Possessed: Deity and Spirit Possession in South Asian Literature and Civilization . New York: Columbia Univ. Press.

Strickmann, Michel. 1996. Mantras et mandarins: Le buddhisme tantrique en Chine. Paris: Gallimard.

Strickmann, Michel. 2002. Chinese Magical Medicine. Edited by Bernard Faure. Stanford: Stanford University Press. Vaidya, Parashuram Lakshman, ed. 1959. Divyāvadānam. Buddhist Sanskrit Texts 20. Darbhaga: The Mithila Institute of Post-Graduate Studies and Research in Sanskrit Learning.

Wujastyk, Dominik. 1999. Miscarriages of Justice: Demonic Vengeance in Classical Indian Medicine. In Religion, Health, and Suffering. Edited by John R. Hinnels and Roy Porter. New York: Routledge, pp. 256-75.

Wujastyk, Dominik. 2003. The Roots of Ayurveda. New York: Penguin Books.

Yoshimura, Shyuki. 1950. bka' bstan dkar chag ldan dkar ma/dbu can bris ma/. Kyoto: Ryukoku University.

(C) 2019 by the author. Licensee MDPI, Basel, Switzerland. This article is an open access article distributed under the terms and conditions of the Creative Commons Attribution (CC BY) license (http:// creativecommons.org/licenses/by/4.0/). 